\title{
Consumer Response to Novel Indoor Foliage Plant Attributes: Evidence from a Conjoint Experiment and Gaze Analysis
}

\author{
Alicia Rihn and Hayk Khachatryan ${ }^{1}$ \\ Food and Resource Economics Department and Mid-Florida Research and \\ Education Center, University of Florida, 2725 S. Binion Road, Apopka, FL \\ 32703
}

\section{Benjamin Campbell \\ Department of Agricultural and Resource Economics, University of Connecticut, 3107 Horsebarn Hill Road, Storrs, CT 06269}

\section{Charles Hall}

Department of Horticultural Sciences, Texas A\&M University, College Station, TX 77843

\section{Bridget Behe}

Department of Horticulture, Michigan State University, East Lansing, MI 48824

Additional index words. consumer behavior, Dracaena marginata, eye-tracking, Guzmania lingulata, purchasing barrier, Spathiphyllum wallisii

\begin{abstract}
A rating-based conjoint experiment combined with eye-tracking analysis was used to investigate the effect of plant attributes on consumer purchase likelihood for indoor foliage plants. The experiment assessed the effects of plant type (Dracaena marginata Lam., Guzmania lingulata, or Spathiphyllum wallisii Regel), volatile organic compound (VOC) removal capacity (high, low, or none specified), price $(\$ 10.98-14.98 /$ plant), production method [certified organic, organic production (not certified), or conventional], and origin (in-state, domestic, or imported) on consumer preferences. An ordered logit model was used to analyze the data. Organic production methods, in-state origin, domestic origin, and high VOC removal increased participants' purchase likelihood. Visually attending to the highest price point (\$14.98) increased consumers' purchase likelihood. Age, gender, child ( $<12$ years), pet, relationship status, education, and ethnicity affected participants' purchase likelihood for indoor foliage plants. Purchasing barriers for indoor foliage plants are also discussed. Results have implications for indoor foliage plant growers and retailers as they produce, promote, and sell their products.
\end{abstract}

Indoor foliage plant production has been an important industry in Florida since 1912, when Boston ferns (Nephrolepis exaltata L.) were first mass produced there (Mitchell, 2008; USDA-NASS, 2012). In 2009, Florida produced $72 \%$ of the United States' indoor foliage plants with a total gross sales value (wholesale and retail) of $\$ 453.5$ million (USDA-NASS, 2012). Recently, many factors have negatively impacted the indoor foliage plant industry including the economic recession (Carter, 2014; Lerman, 2013) and an industry reaching maturity, characterized by business consolidation and overall decreased demand (USDA-NASS, 2014). For instance,

Received for publication 1 Apr. 2015. Accepted for publication 19 June 2015.

We gratefully acknowledge funding from the Florida Department of Agriculture and Consumer Services.

1CCorresponding author. E-mail: hayk@ufl.edu. in 2013, U.S. foliage plant sales decreased 1\% from 2012 (USDA-NASS, 2014). Promoting new plant attributes that are relevant to consumer needs and interests is one strategy to mitigate decreasing demand (Schiffman and Kanuk, 2007). Novel product attributes can meet new market needs, facilitate product differentiation, justify higher price points, and increase profit margins (Schiffman and Kanuk, 2007). However, new product attributes and promotional materials need to align with consumer preferences to be successful. Thus, evaluating consumer preferences toward novel indoor foliage plant attributes is required before growing and promoting plants with those attributes to reduce grower and retailer risk.

Consumers have preferences for plants that benefit the environment and/or improve human health (Behe et al., 2014; Brethour et al., 2007; Hall and Dickson, 2011). Retailers could successfully use health- and wellbeing-related benefit information to increase consumers' interest, but marketers may be unsure of how consumers will react to these specific benefits. Brethour et al. (2007) found that indoor and outdoor ornamental plants provide numerous economic, environmental, and human lifestyle benefits, including reducing noise/light pollution, providing habitat for wildlife, and improving air quality. One unique benefit of indoor foliage plants that is often overlooked is their ability to purify air by removing VOCs (Liu et al., 2007). VOCs are air pollutants (including benzene, formaldehyde, toluene, and xylene) from common household products (such as carpeting, furniture, paint, etc.) that adversely affect human health and reduce air quality (Soreanu et al., 2013; Sunkhapongvitit and Jinsart, 2012; Xu et al., 2011). Many of these benefits are not well understood by the general public, and unlike the food sector, the horticulture (green) industry is among the least proactive in communicating benefit information to promote sales (Brethour et al., 2007; Solano, 2012). Hall and Dickson (2011) suggest the green industry use these benefits in promotions to increase consumers' perceived value. Through increasing perceived value of a product a firm has the potential to increase demand (Salois and Reilly, 2014).

This manuscript offers meaningful contributions to consumer behavior literature on eye-tracking technology, novel plant attributes, and barriers to purchase for indoor foliage plants in Florida. First, eye-tracking technology has been used in the horticulture industry to investigate consumer preferences for plants (Behe et al., 2014). Eye-tracking technology accurately records what consumers view while making purchasing decisions. However, there is still a substantial amount of information to be gained from integrating eye-tracking analysis and other experimental methods (Agarwal et al., 2014). For instance, many experimental methods assume participants view all available product attributes and select the product that provides them the most benefits (i.e., utility theory); however, this may not be true (Hensher and Rose, 2009). Eye-tracking analysis allows researchers to correlate visual attention and subsequent consumer choices.

A second contribution is the investigation of consumers' interest in VOC removal, production methods, and origin (attributes are discussed in the next section). Few studies have quantified the effects of environmental/ human well-being information on consumers' preferences for indoor foliage plants. However, as consumers become increasingly conscious of personal and environmental health, their interest in these attributes will likely increase. Lastly, we determine consumers' primary barriers to purchase indoor foliage plants. To the authors' knowledge, consumers' barriers to purchase for indoor foliage plants have not been investigated in the past. Knowing what hinders consumers' purchasing of indoor foliage plants benefits breeders, developers, growers, marketers, and retailers by giving them the opportunity to address potential barriers before consumers purchasing the product. In the end, addressing barriers to 
purchase can improve the consumers' experience and influence future buying decisions.

\section{Plant Characteristics and Consumer Preferences}

The three plant characteristics of interest were VOC removal, production practices, and product origin. Very few studies address consumers' perceptions of VOC removal for indoor foliage plants. However, since consumers are becoming increasingly health conscious, research suggests leveraging personal health benefits (including VOC removal) in the ornamental plant industry to add value and differentiate products (Brethour et al., 2007; Hall and Dickson, 2011). Solano (2012) investigated consumer willingness to pay for VOC removal by indoor foliage plants. Consumers were willing to pay between $\$ 17.45$ $(74 \%)$ and $\$ 18.40$ more $(90 \%)$ for indoor foliage plants that remove VOCs. However, the amount of VOCs removed by plants varies widely by species (Liu et al., 2007), which may impact consumers' preferences. Despite this variance, studies indicate there is potential to use VOC information to add value and generate consumer interest in indoor foliage plants.

Alternative production practices (i.e., organic production methods) that are ecologically friendly and enhance environmental/ personal health have been shown to affect consumer preferences and demand for products (Haumann, 2012; Hawkins et al., 2012; Schimmenti et al., 2013; Yiridoe et al., 2005). In 2011, U.S. organic industry sales increased $9.5 \%$ to $\$ 31.5$ billion (Haumann, 2012). Although the majority of those sales (93\%) are attributed to organic foods and beverages, there is potential to use alternative production methods to add value to horticultural products (Haumann, 2012; Schimmenti et al., 2013). Increased consumer interest in organic products has been linked to amplified awareness of environmental consequences, social responsibility, healthy lifestyles, and sustainable living (Stewart, 2007). However, before implementing organic production practices, knowing consumer interest is important because considerable financial and labor resources are required for producers to obtain and maintain organic certification (Organic Trade Association, 2013). Previous research on consumer preferences for organic ornamental plants yielded mixed results (Hawkins et al., 2012; Schimmenti et al., 2013; Yue et al., 2011a). Hawkins et al. (2012) and Schimmenti et al. (2013) determined consumers prefer, and are willing to pay more for, organically produced ornamental landscape plants. However, Yue et al. (2011a) found limited consumer interest for organic ornamental landscape plants. The inconclusive results paired with limited studies on consumer preferences for organic indoor foliage plants leads one to question-how do organic production methods impact consumer preferences for indoor foliage plants? Although indoor foliage plants are not exposed to the outside environment, they contribute to indoor environments where people may be exposed to the chemicals (i.e., pesticides and fertilizers) that have been used to grow them (Stewart, 2007). Furthermore, consumers are becoming more conscious of long-term environmental health impacts, which may increase their awareness and desire for organic indoor foliage plants (Brethour et al., 2007; Hall and Dickson, 2011). To the authors' knowledge, currently there are no studies investigating the effect of organic production promotions on consumers' purchase likelihood for indoor foliage plants.

The last attribute is product origin. Evidence suggests that consumers are interested in origin information, especially on food products (Adams and Salois, 2010; Collart et al., 2013; Curtis and Cowee, 2010; Keeling-Bond et al., 2009; Onozaka et al., 2010). Bond et al. (2009) suggests using locally grown promotions to add value to food products. Locally produced foods are associated with supporting the local economy/ community, improved product quality/safety, superior product nutrition, and decreased transportation miles (Adams and Salois, 2010; Onozaka et al., 2010). Due to these perceived benefits, consumers are willing to pay $10 \%$ to $170 \%$ more to obtain locally produced foods (Adams and Salois, 2010). However, few studies have addressed origin with ornamental plants and those studies have primarily focused on state-specific promotional campaigns, sales, and willingness to pay (Anella et al., 2001; Collart et al., 2010; Curtis and Cowee, 2010; Wehry et al., 2007; Winter et al., 2001; Yue et al., 2011a). Anella et al. (2001) found the "Oklahoma Proven" plant campaign increased landscape plant sales by $81 \%$. Collart et al. (2013) estimated consumers are willing to pay $10.4 \%$ more for state-branded (Texas Superstar ${ }^{(\mathbb{B}}$ ) ornamental plants. Similarly, Curtis and Cowee (2010) determined Nevada homeowners were willing to pay a $14 \%$ premium for origin-certified (NevadaGrown) native plants. Local plants are perceived as being acclimated to the local environment and thus are more likely to survive (Curtis and Cowee, 2010; Wehry et al., 2007). State and local promotional programs positively impact consumer preferences for ornamental landscape plants, but do these benefits extend to indoor foliage plants? Since indoor foliage plants are not exposed to external environmental conditions, acclimation is not likely a concern. However, other benefits of origin (i.e., local economy support, quality/freshness, etc.) may affect consumer purchasing behavior for indoor foliage plants.

\section{Research Goals and Hypotheses}

This study has two primary research goals. First, we propose to identify consumers' purchasing barriers for indoor foliage plants. Identifying purchasing barriers provides valuable information to green industry professionals since marketing strategies can then be created to overcome those barriers and increase sales. The second goal of our research was to determine consumer interest in different VOC removal levels, production practices, and origins on indoor foliage plants. We tested several hypotheses. First, we hypothesize organic production practices will positively influence consumer purchasing preferences for indoor foliage plants. Previous research on ornamental landscape plants indicates there may be a niche market for organic ornamental plants due to perceptions of personal and environmental health benefits (Hawkins et al., 2012; Schimmenti et al., 2013). In turn, this may provide a profitable means of generating consumer interest and adding value to indoor foliage plants. Second, we hypothesize in-state and/or domestic origins will be preferred over imported plants. Third, we hypothesize VOC removal information positively affects consumer purchasing behavior for indoor foliage plants. We speculate that consumers will prefer indoor foliage plants with the greatest VOC removing capacity [similar to Solano (2012)]. Lastly, we hypothesize visual attention to the beneficial attributes will positively impact participants' likelihood of purchase. We anticipate greater visual attention to important plant attributes, as shown by Behe et al. (2014).

In this manuscript, we assessed consumers' perceived value of indoor foliage plants by examining consumer preference for various VOC removal rates, production methods, and origins. Specifically, rating-based conjoint analysis was combined with eye-tracking technology as participants determined their purchase likelihood for indoor foliage plants. After completion of the conjoint/eye-tracking portion of the survey, participants were asked demographic and purchasing barrier questions.

\section{Materials and Methods}

Rating-based conjoint analysis experiments (Behe et al., 2005; Mason et al., 2008) and eye-tracking analysis (Behe et al., 2014; Khachatryan et al., 2013) were used to assess consumer behavior toward indoor foliage plant attributes. Recently, conjoint analysis experiments have been paired with eyetracking analysis to better understand consumer information acquisition behavior for horticulture products (Behe et al., 2014; Khachatryan et al., 2013). Unlike other research methods, eye-tracking analysis shows real information acquisition behavior, which can be used to shape future promotional efforts in the retail horticulture industry (Behe et al., 2013). In addition, eye-tracking analysis provides researchers a way to determine which attributes are visually attended by participants and which are ignored [termed "attribute nonattendance" (Van Loo et al., 2014)].

Plant attributes and levels. Plant attributes, levels, and definitions are provided in Table 1. The attributes of plant type, price, production method, origin, and VOC removal capacity resulted in a total of $243\left(3^{5}\right)$ possible rating scenarios. To avoid participant fatigue, SPSS (IBM Software, Armonk, NY) was used to generate a fractional factorial design of 16 scenarios for participants to evaluate. VOC removal levels were low VOC removal (removes $<50 \%$ of VOCs), high VOC removal (removes $>50 \%$ of VOCs), and no label. Production methods included certified organic, 
organic production (defined as "grown using organic production methods but not certified"), and conventional. Origin included Fresh from Florida (in-state), grown in the United States (domestic), and grown outside the United States (imported). Dragon tree ( $D$. marginata Lam.), peace lily ( $S$. wallisii Regel), and bromeliad ( $G$. lingulata) represented different types of indoor foliage plants that are relatively common and potentially recognizable to a wide range of consumers. Price points included $\$ 10.98, \$ 12.98$, and $\$ 14.98$ per plant. Price points were developed based on retail observations (i.e., big box stores, grocery stores, and independent garden centers) in Florida. All attribute levels were defined for participants before the experiment.

Experimental procedure. The experiment took place in central Florida in June 2014. Central Florida was used as the study location for several reasons. First, to facilitate the use of eye-tracking technology participants needed to be physically present. In addition, researchers had access to a centrally located facility in central Florida with ample space for the experiment. Printed flyers were distributed at independent garden centers, public gardens, and on community boards to recruit participants. Advertisements were also placed in local newspapers and on Craigslist to attract a wider demographic of participants.

The experiment consisted of two stages: 1) rating of plants with the recording of visual behavior and 2) a follow-up survey. In the first stage, a Tobii X1 Light Eye Tracker (Tobii Technology, Stockhom, Sweden) was used to record eye movements as participants viewed the plant images. Once the eyetracking camera was calibrated to the subject, participants viewed instruction slides, which defined the attributes and stated that all of the plants had the same care requirements and container size. These parameters were provided to minimize nontarget attribute variance between scenarios. After the instruction slides, a nontarget plant (tomato) was used as an example to familiarize participants with the experimental procedure. Participants were then directed to consider their budget constraint when making purchase likelihood decisions as well as being advised that they could go through the scenario images at their own pace since time pressure can affect visual search behavior (Armel et al., 2008).

For each of the 16 scenarios, participants viewed an image on a computer screen consisting of five identical plants on a wooden bench with a white background (Fig. 1). In-store signs $(1.78 \times 3.89 \mathrm{~cm})$ were used to convey the attributes. Each attribute sign had the same font (Times New Roman), font size, style, and color (turquoise, RGB: 0, 120, 174). The font characteristics were selected to match the text in the "Fresh from Florida" logo to eliminate visual discrepancies between the attributes. The order of the attribute signs was randomized to minimize any potential location effects. Participants were asked to view each image and rate their "purchase likelihood" for the plant on a 7 -point scale $(1=$ very unlikely; 7 = very likely). Participants did not actually purchase

Table 1. Rating-based choice experiment attributes and attribute levels.

\begin{tabular}{|c|c|c|}
\hline Attribute & Definition & Attribute levels \\
\hline Plant type & $\begin{array}{l}\text { Type of plant used in each } \\
\text { scenario }\end{array}$ & $\begin{array}{l}\text { Dracaena marginata Lam. (dragon tree) } \\
\text { Spathiphyllum wallisii Regel (peace lily) } \\
\text { Guzmania lingulata (bromeliad) }\end{array}$ \\
\hline Price $^{z}$ & Price per plant & $\begin{array}{r}\$ 10.98 \\
\$ 12.98 \\
\$ 14.98\end{array}$ \\
\hline Production method & $\begin{array}{l}\text { Description of how the plants } \\
\text { were produced }\end{array}$ & $\begin{array}{l}\text { Certified organic }^{\mathrm{y}} \\
\text { Organic production } \\
\text { Conventional-no label }\end{array}$ \\
\hline Origin & $\begin{array}{l}\text { Description of where the plants } \\
\text { were produced }\end{array}$ & $\begin{array}{l}\text { Fresh from Florida }(\log 0)^{\mathrm{w}} \\
\text { Grown outside the United States } \\
\text { Grown in the United States }\end{array}$ \\
\hline VOC removal ${ }^{\mathrm{v}}$ & $\begin{array}{l}\text { Percent of VOCs the plants } \\
\text { removes from their immediate } \\
\text { surroundings }\end{array}$ & $\begin{array}{l}\text { Low VOC removal } \\
\text { High VOC removal } \\
\text { No label }\end{array}$ \\
\hline
\end{tabular}

zPrice points were determined based on retail observations in Florida (i.e., big box stores, grocery stores, and independent garden centers).

"Certified organic was defined as "product is certified as organically produced."

"Organic production was defined as "product was produced in an organic manner but is not certified."

whe Fresh from Florida attribute level was communicated to participants using the Fresh from Florida logo developed by the Florida Department of Agriculture and Consumer Services (FDACS). Researchers obtained permission from FDACS to use the logo.

${ }^{v}$ VOC (volatile organic compound) removal rates were based on Liu et al. (2007) results, which showed the majority of plants remove $60 \%$ to $80 \%$ of VOCs or $20 \%$ to $40 \%$ of VOCs.

"Low VOC removal was defined as "the plant removes $<50 \%$ of VOCs from its immediate surroundings."

tHigh VOC removal was defined as "the plant removes $>50 \%$ of VOCs from its immediate surroundings."

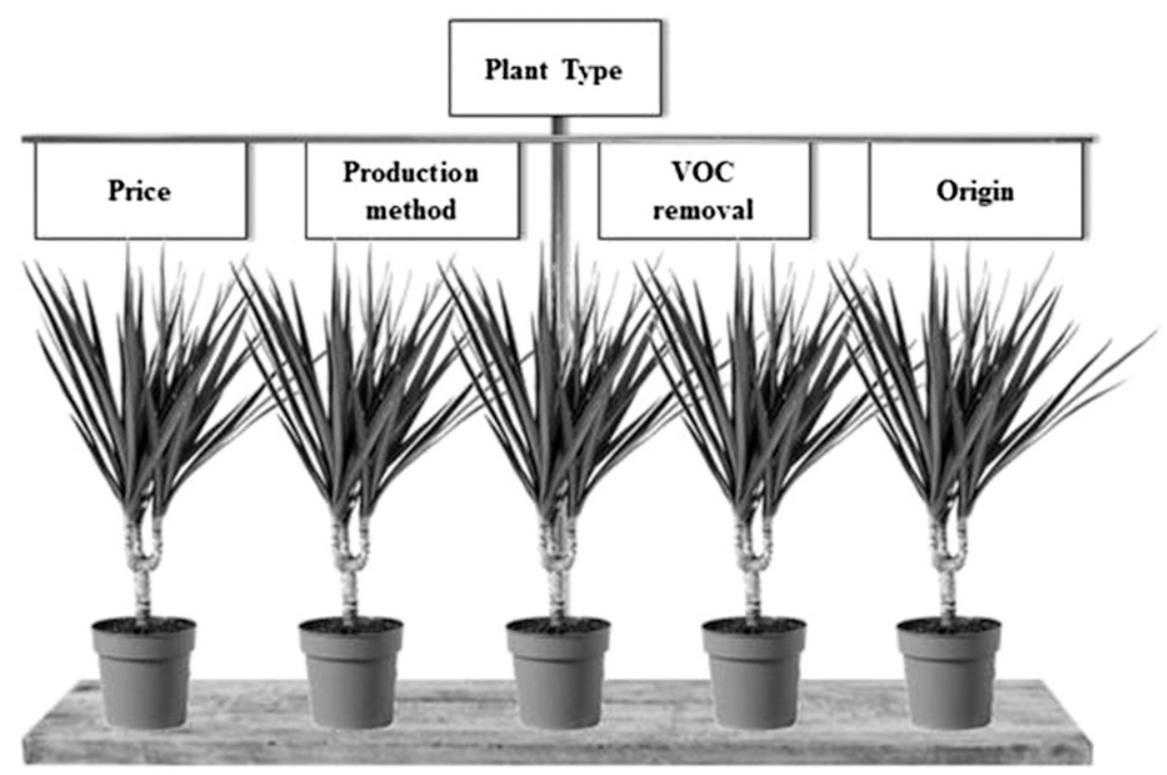

Fig. 1. Example of an indoor foliage plant image from a consumer preference study conducted in 2014 . Note: Images were $19.05 \times 25.4 \mathrm{~cm}$ wide and were located in the center of a 58.4 -cm computer screen $(1920 \times 1080$ pixel resolution $)$.

the plants but instead indicated their purchase likelihood.

On completion of the conjoint analysis experiment, participants completed a survey (stage 2) in Qualtrics Online Survey Software (Qualtrics, LLC, Provo, UT). Questionnaire questions included barriers to purchase and sociodemographic questions. Ninety-one participants completed the rating-based conjoint analysis and eye-tracking experiment. Sample size was deemed acceptable because previous eye-tracking experiments used between 37 (Reisen et al., 2008) and 100 participants (Zhang et al., 2009). Participation lasted $\approx 30 \mathrm{~min}$, and participants were compensated $\$ 30$ for their time.
Visual attention data preparation. After the experiment, Tobii Studio 3.2.2 Software was used to define areas of interest (AOI) for each scenario image. AOI are specific zones within the image (i.e., around each of the attribute signs and plants) that are used in visual data analysis (Behe et al., 2013). Participants' visual data were collected for each AOI. In our experiment, six AOI were defined for each scenario corresponding to plant type, price, production method, origin, VOC removal, and the plant image. Fixation count metrics were extracted for each AOI. Fixation counts can be defined as the total number of eye fixations in each AOI and indicate visual attention to the different plant 
attributes. Since all attribute levels were not present in each scenario image, the visual attention metrics were coded to reflect visual attendance to each specific attribute. Similar to Van Loo et al. (2014), visual attention dummy variables were generated for each attribute, where 1 equals more than two fixations and 0 otherwise. Each visual attention dummy variable only included the fixation counts from scenarios with that specific attribute level. For instance, consider the certified organic attribute. For simplicity purposes, assume scenarios 1 and 3 contained the certified organic attribute. Let $\mathrm{FC}_{\text {certorg }}$ indicate the total number of fixations on the certified organic attribute for each scenario and let attend certorg $_{\text {represent }}$ visual attendance to the certified organic attribute. So, for scenarios 1 and 3 the attend $d_{\text {certorg }}$ variable can be defined as

$$
\text { Attend }_{\text {certorg }}=1 \text { if } \mathrm{FC}_{\text {certorg }}>2
$$

These variables were then used to generate an average attendance $\left(\mathrm{FCA}_{\text {certorg }}\right)$ variable for certified organic

$$
\mathrm{FCA}_{\text {certorg }}=\frac{\left(\text { Attend }_{\text {certorg1 }}+\text { Attend }_{\text {certorg } 3}\right)}{2}
$$

Situations where certain attributes were not present in the choice scenarios are controlled by indicator variables described in the "Plant attributes and levels" section.

Ordinal regression model description. STATA/IC 11 Software (StataCorp LP, College Station, TX) was used for the data analysis. Since the dependent variable (purchase likelihood) was a rating score, an ordered logit model was used to analyze the impact of the attributes and participants' visual attention had on their purchase likelihood. Specifically, the ordered logit model can be described following Long and Freese's (2006) notation, where $y^{*}{ }_{i}$ is a latent variable ranging from $-\infty$ to $\infty$. Specifically,

$$
y_{i}^{*}=x_{i} \beta+\varepsilon_{i}
$$

where $i$ is an observation and $\varepsilon_{i}$ is a random error term for observation $i$. The continuous latent variable is the participant's purchase likelihood rating. The latent variable and observed response categories are connected by:

$$
y_{i}=\left\{\begin{array}{ccc}
1 & \text { if } & \kappa_{0}=-\infty \leq y_{i}^{*}<\kappa_{1} \\
2 & \text { if } & \kappa_{1} \leq y_{i}^{*}<\kappa_{2} \\
\vdots & \vdots & \vdots \\
7 & \text { if } & \kappa_{6} \leq y_{i}^{*}<\kappa_{7}=\infty
\end{array}\right.
$$

where crossing each threshold $(k)$ results in a category change. Consequently, the probability of observing $y=j$ for the values of $x$ can be expressed as:

$$
\operatorname{Pr}(y=j \mid x)=\operatorname{Pr}\left(k_{j-1} \leq y^{*}<k_{j} \mid x\right)
$$

where $j=1$ to $J$ (purchase likelihood rating). By replacing $y^{*}$ with $x \beta+\varepsilon$ we can determine the probability of a specific rating. Therefore, the predicted probability is

$$
\operatorname{Pr}(y=j \mid x)=F\left(k_{j}-x \beta\right)-F\left(k_{j-1}-x \beta\right)
$$

where $F$ indicates the cumulative distribution function of $\varepsilon$ and, in this instance, is $\operatorname{Var}(\varepsilon)=\pi^{2} / 3$.

\section{Results}

Participants were on average 47 years old and 33\% were male (Table 2). Participants' 2013 mean gross household income fell in the category of $\$ 51,000-60,000$. Participants' education level was between an associate's degree and a 4-year college degree. The mean household size was 2.5 people and $10 \%$ of the sample had a child ( $<12$ years) in their household. Sixty-four percent of participants were married or in a relationship. Nearly $70 \%$ of participants had indoor pets. Seventy-three percent of the sample described their ethnicity as "white/Caucasian." Florida state census data are provided for comparison (U.S. Census Bureau, 2014). In general, the sample appears to have completed a higher level of education, earned a higher income, and consisted of a higher percentage of females than Florida's population. These differences are likely due to the study topic since core consumers of plants and gardening items tend to be older women with higher incomes (Mason et al., 2008).

Barriers to purchase. In the survey, participants were asked to rank potential barriers preventing them from purchasing indoor foliage plants (Fig. 2). The primary factors were plant

\begin{tabular}{|c|c|c|c|}
\hline Variable & Description of variables & Mean $\pm \mathrm{SE}$ & Florida census data ${ }^{\mathrm{z}}$ \\
\hline$\overline{\text { Age }}$ & Average age (in years) of participant & $46.965 \pm 18.948$ & $\begin{array}{l}21 \%<18 \text { years } \\
19 \%>65 \text { years }\end{array}$ \\
\hline Gender & $\begin{array}{l}\text { Gender of participant } \\
1=\text { male } \\
0=\text { female }\end{array}$ & $0.330 \pm 0.470$ & 0.499 \\
\hline Income & $\begin{array}{l}2013 \text { gross household income of } \\
\text { participants } \\
1=<\$ 20 \mathrm{~K} \\
2=\$ 21-30 \mathrm{~K} \\
3=\$ 31-40 \mathrm{~K} \\
4=\$ 41-50 \mathrm{~K} \\
5=\$ 51-60 \mathrm{~K} \\
6=\$ 61-70 \mathrm{~K} \\
7=\$ 71-80 \mathrm{~K} \\
8=\$ 81-90 \mathrm{~K} \\
9=\$ 91-100 \mathrm{~K} \\
10 \geq \$ 100 \mathrm{~K}\end{array}$ & $5.126 \pm 3.128$ & $\$ 47,309$ \\
\hline Child & $\begin{array}{l}\text { Household includes at least one child } \\
\text { less than } 12 \text { years }\end{array}$ & $0.101 \pm 0.302$ & $\mathrm{na}^{\mathrm{y}}$ \\
\hline Pet & Household has an indoor pet & $0.697 \pm 0.460$ & na \\
\hline Relationship & $\begin{array}{l}\text { Relationship status of participant } \\
1=\text { in a relationship/married } \\
0=\text { not married/single, divorced } / \\
\quad \text { separated, widowed }\end{array}$ & $0.637 \pm 0.481$ & na \\
\hline Household & Number of people in household & $2.495 \pm 2.125$ & 2.58 \\
\hline Education & $\begin{array}{l}\text { Highest level of education completed } \\
1=\text { some high school } \\
2=\text { high school diploma/GED } \\
3=\text { some college } \\
4=\text { associates degree } \\
5=\text { college diploma } \\
6=\text { some graduate school } \\
7=\text { graduate degree }\end{array}$ & $4.385 \pm 1.734$ & $\begin{array}{l}85.8 \% \text { earned high school } \\
\text { degree or higher }\end{array}$ \\
\hline Ethnicity & $\begin{array}{l}\text { Ethnic background of participants } \\
1=\text { white/Caucasian } \\
0=\text { other }\end{array}$ & $0.725 \pm 0.447$ & $78.1 \%$ Caucasian \\
\hline
\end{tabular}
maintenance (including irrigation and fertilization requirements), price, limited space and light, negative reaction to plant death, potential to attract bugs, personal/family member allergies,

Table 2. Sample summary statistics $(\mathrm{n}=91)$.

${ }^{\mathrm{z}}$ U.S. Census Bureau (2014).

${ }^{y}$ na $=$ not available. potential toxicity to pets, and "other" (including "do not think about purchasing plants," no wildlife benefit, mold problems, odd odors, and "air conditioning kills them"; Fig. 2). Less frequently selected barriers included lack of selection, dislike plants, and child toxicity concerns. The significance test (i.e., pairwise $t$ tests) showed price, limited space, and limited light were similar in terms of being the largest barriers to purchase (Table 3). Next, the "I feel bad if I kill the plant," attracts bugs, "other," and lack of selection options were similar in terms of being selected as barriers. Allergy concerns were similar in terms of importance to pet toxicity, but both were less of a barrier compared with other barrier options. Least important barriers to purchase included the "I do not like plants" option and child toxicity concerns.

Purchasing likelihood and novel plant attributes. Plant type, production method, origin, and VOC removal impacted consumers' purchase likelihood. On average, peace lilies were preferred over dragon trees, but dragon trees and bromeliads had a similar level of consumer preference (Table 4). Certified organic and organic production methods had a positive relationship with consumers' purchase likelihood for indoor foliage plants when compared with conventional production methods, supporting our first hypothesis. Results were consistent with Hawkins et al. (2012) and Schimmenti et al. (2013) who both found 
increased consumer interest in organic ornamental plants.

Consumers' purchasing likelihood was also influenced by product origin. Compared with imported indoor foliage plants, participants were more likely to purchase in-state or domestically grown plants, supporting the second hypothesis (Table 4). Our results are compatible with several ornamental plant studies that found consumers prefer in-state origins (Anella et al., 2001; Collart et al., 2013; Winter et al., 2001).

Consumers were more likely to purchase indoor foliage plants with high VOC removal capacity than plants with no VOC rating, which was consistent with previous research (Table 4; Solano, 2012). The low VOC removal designation had a negative impact on participants' purchasing likelihood. The VOC removal results partially support the third hypothesis that VOC removal positively affects purchasing likelihood in that higher VOC removal levels had a positive impact.

Sociodemographic characteristics also impacted participants' purchase likelihood. Older consumers were less likely to purchase indoor foliage plants (Table 4). Compared with women, men were less likely to purchase

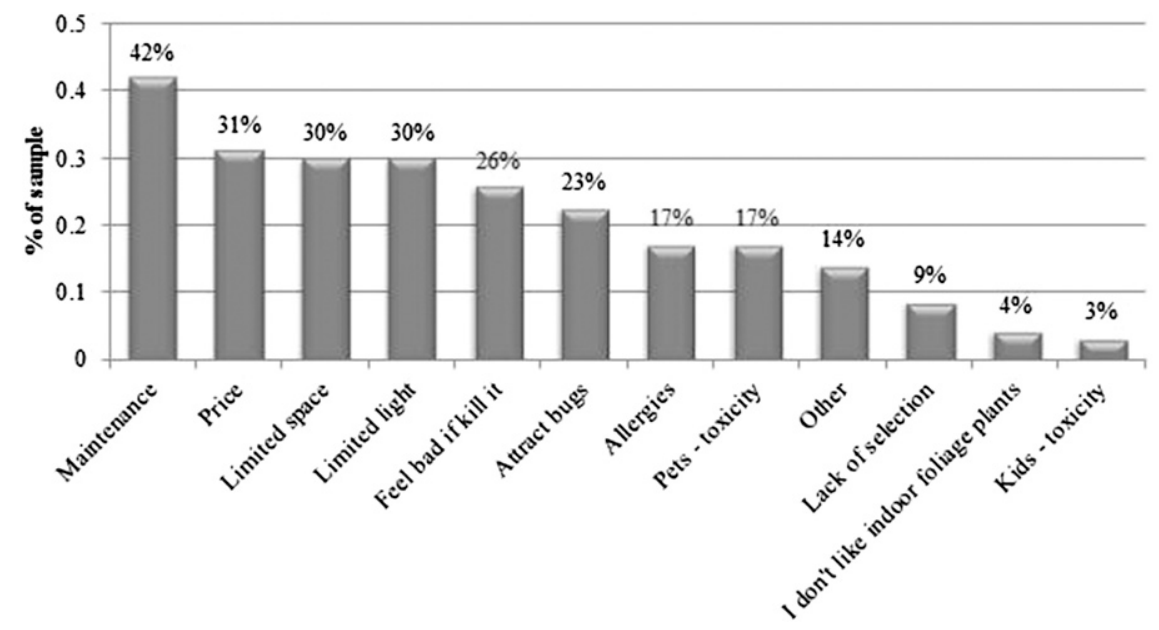

Fig. 2. Percent of participants indicating their barriers to purchase for indoor foliage plants $(n=91)$. Note: Participants were asked to "check all that apply" therefore the percentages do not sum to $100 \%$. Maintenance included fertilization and irrigation requirements. Participants indicated other attributes including "I do not think about the barriers," "they do not benefit wildlife," mold and odor issues, "air conditioning kills them," and traveling too often to care for the plants. mary purchasers of ornamental plants (Mason et al., 2008). Participants with a child or indoor pet were less likely to purchase the indoor foliage plants potentially due to limited time (for care/maintenance) or toxicity concerns as noted in the barriers to purchase section. A higher education level or being of white/ Caucasian ethnicity decreased purchase likelihood. Participants who were in a relationship were more likely to purchase the plants. Income and household size were not significant.

Fixation count attendance (FCA) variables were used as a measure of visual attention. FCA coefficients can be interpreted as the impact on the consumer's purchasing likelihood if the participant visually attended the attribute (meaning they fixated on the attribute more than two times; Van Loo et al., 2014). Visual attention to the plant image decreased participants purchase likelihood (Table 4). Visual attention to the highest price (\$14.98) improved participants' purchase likelihood. Participants who viewed the domestic origin sign were less likely to purchase the plant. Visual attention to the lowest price (\$10.98), middle price $(\$ 12.98)$, indoor foliage plants. This was consistent with previous research stating women are the pri-

Table 3. Pairwise $t$ test results of consumers' purchasing barriers for indoor foliage plants $(\mathrm{n}=91)$.

\begin{tabular}{|c|c|c|c|c|c|c|c|c|c|c|c|c|}
\hline & Maintenance & Price & $\begin{array}{l}\text { Limited } \\
\text { space }\end{array}$ & $\begin{array}{c}\text { Limited } \\
\text { light }\end{array}$ & $\begin{array}{c}\text { Feel bad } \\
\text { if kill }\end{array}$ & Bugs & Allergies & $\begin{array}{c}\text { Pet } \\
\text { toxicity }\end{array}$ & Other & No selection & $\begin{array}{l}\text { Do not } \\
\text { like }\end{array}$ & $\begin{array}{c}\text { Kid } \\
\text { toxicity }\end{array}$ \\
\hline Price & & - & 0.718 & 0.676 & $3.495 * * *$ & $5.544 * * *$ & $9.315^{* * *}$ & $9.315^{* * *}$ & $10.491^{* * *}$ & $15.824 * * *$ & $19.552 * * *$ & $22.916^{* * *}$ \\
\hline Feel bad if kill & & & & & - & $2.158^{*}$ & $5.718 * * *$ & $6.123 * * *$ & $7.816^{* * *}$ & $12.747 * * *$ & $18.059 * * *$ & $18.702 * * *$ \\
\hline Bugs & & & & & & - & $4.620 * * *$ & $4.021^{* * *}$ & $5.910 * * *$ & $11.880 * * *$ & $17.086^{* * *}$ & $18.938^{* * *}$ \\
\hline Allergies & & & & & & & - & 0.000 & $2.313^{*}$ & $8.179 * * *$ & $11.842 * * *$ & $14.337 * * *$ \\
\hline No selection & & & & & & & & & & - & $4.651 * * *$ & $6.768 * * *$ \\
\hline Do not like & & & & & & & & & & & - & 1.513 \\
\hline Kid toxicity & & & & & & & & & & & & - \\
\hline
\end{tabular}

certified organic, organic production, conventional, in-state, import, low VOC removal, and high VOC removal signs did not influence purchase likelihood. The visual attention results partially support the fourth hypothesis (visual attention to beneficial attributes will positively impact consumers' willingness to purchase indoor foliage plants) for the production method attributes since conventional production was negative and significant. However, the fourth hypothesis was not supported for origin or VOC

\section{Discussion}

Declining consumer demand for indoor foliage plants highlights the importance of knowing consumers' needs in stimulating plant sales. Through a conjoint analysis and eyetracking experiment, this study identifies consumers' purchasing barriers and assesses novel indoor foliage plant attributes as a means of stimulating consumer interest. The purchasing barrier results can be used by horticulture professionals to design, breed, promote, and sell indoor foliage plants that better align with consumer needs. For instance, indoor foliage plant maintenance was the most common purchasing barrier selected by participants. Growers and retailers could grow and sell low-maintenance plants to address this barrier. They could also promote products that reduce the plant maintenance requirements (such as self-watering containers and slow-release fertilizers). Price, limited light, and limited space were all comparable purchasing barriers suggesting a possible niche market for inexpensive, small, low light tolerant indoor foliage plants.

In addition, our results provide evidence in support of using novel (production method, origin, and VOC removal) attributes in the indoor foliage plant industry. Alternative (i.e., organic) production methods positively influence consumer purchasing behavior for indoor foliage plants. There is potential for growers and retailers to leverage these attributes as a means to differentiate indoor foliage plants, provided additional costs of production associated with organic production are not prohibitive. The results may be related to consumers increased interest in improved environmental and personal health. Consequently, there could be a market segment interested in organic indoor foliage plants. Growers and retailers could removal attributes.

*, **, ***Indicate $P$ values of $\leq 0.001, \leq 0.01$, and $\leq 0.05$, respectively. 
Table 4. Ordered logit regression coefficient estimates of consumers' purchase likelihood for novel indoor foliage plant attributes $(\mathrm{n}=91)$.

\begin{tabular}{|c|c|c|}
\hline & Coefficient $\pm \mathrm{SE}$ & \\
\hline \multicolumn{3}{|l|}{ Attributes } \\
\hline Plant type-Draceana & $-0.865 \pm 0.127$ & $* * *$ \\
\hline Plant type-Bromeliad & $0.260 \pm 0.142$ & \\
\hline Plant type-Spathiphyllum & Base & \\
\hline Price & $-0.055 \pm 0.031$ & \\
\hline Certified organic & $0.529 \pm 0.124$ & *** \\
\hline Organic production & $0.389 \pm 0.138$ & ** \\
\hline Conventional & Base & \\
\hline In-state (Fresh from Florida) & $0.981 \pm 0.131$ & *** \\
\hline Domestic (grown in the United States) & $0.720 \pm 0.144$ & $* * *$ \\
\hline Import (grown outside the United States) & Base & \\
\hline Low VOC & $-0.348 \pm 0.136$ & ** \\
\hline High VOC & $0.581 \pm 0.129$ & $* * *$ \\
\hline No VOC & Base & \\
\hline \multicolumn{3}{|l|}{ Sociodemographics } \\
\hline Age & $-0.009 \pm 0.004$ & * \\
\hline Gender (male) & $-0.464 \pm 0.128$ & $* * *$ \\
\hline Income & $0.020 \pm 0.021$ & \\
\hline Child & $-0.865 \pm 0.255$ & $* * *$ \\
\hline Pet & $-0.839 \pm 0.121$ & $* * *$ \\
\hline In relationship & $0.380 \pm 0.124$ & ** \\
\hline Household & $-0.003 \pm 0.032$ & \\
\hline Education & $-0.102 \pm 0.040$ & * \\
\hline Ethnicity & $-0.404 \pm 0.126$ & $* * *$ \\
\hline \multicolumn{3}{|l|}{ Eye-tracking variables ${ }^{2}$} \\
\hline FCA_plant & $-0.752 \pm 0.316$ & * \\
\hline FCA_price1098 & $0.466 \pm 0.272$ & \\
\hline FCA_price1298 & $-0.037 \pm 0.261$ & \\
\hline FCA_price1498 & $1.585 \pm 0.339$ & *** \\
\hline FCA_certified organic & $0.165 \pm 0.352$ & \\
\hline FCA_organic production & $-0.085 \pm 0.310$ & \\
\hline FCA_conventional & $-0.525 \pm 0.307$ & \\
\hline FCA_in-state & $0.772 \pm 0.420$ & \\
\hline FCA_domestic & $-1.441 \pm 0.294$ & $* * *$ \\
\hline FCA_import & $0.269 \pm 0.294$ & \\
\hline FCA_low VOC & $0.159 \pm 0.315$ & \\
\hline FCA_high VOC & $-0.531 \pm 0.375$ & \\
\hline \multicolumn{3}{|l|}{ Threshold parameters } \\
\hline 1 & $-4.113 \pm 0.593$ & \\
\hline 2 & $-3.299 \pm 0.592$ & \\
\hline 3 & $-2.716 \pm 0.591$ & \\
\hline 4 & $-2.195 \pm 0.589$ & \\
\hline 5 & $-1.221 \pm 0.586$ & \\
\hline 6 & $0.203 \pm 0.585$ & \\
\hline Log-likelihood & -2176.558 & \\
\hline LR Chi2 (30) & 373.78 & \\
\hline Prob $>$ Chi 2 & $<0.001$ & \\
\hline Number of observations & 1248 & \\
\hline
\end{tabular}

$*, * *, * * *$ Indicate $P$ values of $\leq 0.001, \leq 0.01$, and $\leq 0.05$ when compared with the base variables.

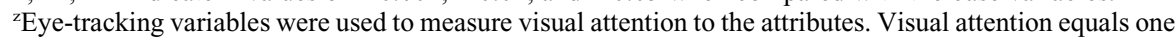
if the participant fixated on the attribute more than two times (as discussed by Van Loo et al., 2014). FCA $=$ Fixation count attendance.

Note: A higher coefficient indicates a higher purchase likelihood when compared with the base variable.

benefit through producing and selling indoor foliage plants grown using these alternative production methods. Although it is outside the scope of this study, the benefits provided by organic production methods (i.e., environmental health, reduced pesticide residues, etc.) have potential to influence consumer choices. Future studies could explore the influence of different organic production method benefits to assist with indoor foliage plant marketing efforts.

Retailers could benefit through sourcing plants from in-state and domestic growers. In-state and domestic origins should be emphasized with in-store promotions. The benefits associated with close origins (i.e., supporting the local economy, decreased transportation distances, and increased quality) low level then became the base level. Consequently, low VOC removal decreased purchase likelihood. Alternatively, participants may have been skeptical of indoor foliage plants' ability to remove VOCs or not cared about the VOC removal attribute. Overall, our results indicate that VOC removal promotions could add value to plants with high VOC removal potential. Consumer interest in personal and family health likely influenced these results. There is an opportunity for indoor foliage plant growers and retailers to use VOC attributes to improve consumers' perceived value for indoor foliage plants. Educational promotions could be used to inform consumers about VOCs, their source, and plants that remove them from the consumers' homes. Previous research indicates that providing additional information about VOCs improves the plant's value to end consumers (Solano, 2012). Future research could be used to address the cutoff values for VOC removal capacity and to further investigate consumer interest.

Visual attention to the highest plant price increased participants' purchase likelihood. There are several possible explanations for this result. First, consumers use very few pieces of information before arriving at a purchase decision (Olson and Jacoby, 1972), often relying mainly on price (Dodds and Monroe, 1985; Jacoby et al., 1971; Kardes et al., 2004). Secondly, the study's participants likely were undecided on their purchasing intention and used price as their deciding attribute. The heuristic that price equals quality where the highest priced item is the highest quality item may have impacted this result. Another possible explanation is participants were assigned to evaluate indoor foliage plants without being screened for being a purchaser of indoor foliage plants. As a result, they may have been unfamiliar with the products and their prices. Although the price levels in the study accurately reflect the prices found within the study area, the participants may not have been familiar with the product that would influence their perceptions of the price points and make it more difficult for them to decide on their purchase likelihood. The visual attention to prices results provide interesting questions for future research on correlations between visual attention, price, heuristics, and consumer perceptions.

Although our results provide interesting implications for novel indoor foliage plant attributes, one limitation of this study is a localized sample. Participants were recruited in central Florida and needed to be on-site to facilitate the use of the eye-tracking technology. A localized sample indicates the results may not be representative of other U.S. regions. However, previous studies have successfully used localized samples to investigate consumer preferences for horticultural products (Phillips et al., 2007; Wehry et al., 2007; Yue et al., 2011b). To counter this limitation, additional experiments in other regions could be used to test the robustness of results. 


\section{Literature Cited}

Adams, D.C. and M.J. Salois. 2010. Local versus organic: A turn in consumer preferences and willingness-to-pay. Renew. Agr. Food Syst. 25:331-341.

Agarwal, J., W.S. DeSarbo, N.K. Malhotra, and V.R. Rao. 2014. An interdisciplinary review of research in conjoint analysis: Recent developments and directions for future research. Cust. Needs and Solut. 1-22.

Anella, L.B., M.A. Schnelle, and D.M. Maronek. 2001. Oklahoma Proven: A plant evaluation and marketing program. HortTechnology 11:381384.

Armel, K.C., A. Beaumel, and A. Rangel. 2008. Biasing simple choices by manipulating relative visual attention. Judgm. Decis. Mak. 3:396403.

Behe, B.K., B. Campbell, H. Khachatryan, C.R. Hall, J.H. Dennis, P.T. Huddleston, and R.T. Fernandez. 2014. Incorporating eye tracking technology and conjoint analysis to better understand the green industry consumer. HortScience 49:1550-1557.

Behe, B.K., J. Hardy, S. Barton, J. Brooker, R.T. Fernandez, C.R. Hall, J. Hicks, R. Hinson, P. Knight, R. McNiel, T. Page, B. Rowe, C. Safley, and R. Schutzki. 2005. Landscape plant material, size, and design sophistication increase perceived home value. J. Environ. Hort. 23:127-133.

Behe, B.K., R.T. Fernandez, P.T. Huddleston, S. Minahan, K.L. Getter, L. Sage, and A.M. Jones. 2013. Practical field use of eye-tracking devices for consumer research in the retail environment. HortTechnology 23:517-524.

Bond, J.K., D. Thilmany, and C. Bond. 2009. What influences consumer choice of fresh produce purchase location? J. Agr. Appl. Econ. 41(1):62-74.

Brethour, C., G. Watson, B. Sparling, D. Bucknell, and T. Moore. 2007. Literature review of documented health and environmental benefits derived from ornamental horticulture products. Agr. and Agri-Food Canada Markets and Trade, George Morris Center, 69.

Carter, B. 2014. Late bloomer: Income growth spurs demand, but consumers will turn to alternative operators. IBISWorld Industry Report 45311 Florists in the US 1-32.

Collart, A.J., M.A. Palma, and C.E. Carpio. 2013. Consumer response to point of purchase advertising for local brands. J. Agr. Appl. Econ. 45:229-242.

Collart, A.J., M.A. Palma, and C.R. Hall. 2010. Branding awareness and willingness-to-pay associated with the Texas Superstar ${ }^{\mathrm{TM}}$ and Earth-Kind ${ }^{\mathrm{TM}}$ brands in Texas. HortScience 45:1226-1231.

Curtis, K.R. and M.W. Cowee. 2010. Are homeowners willing to pay for "origincertified" plants in water conserving residential landscaping? J. Agr. Res. Econ. 35(1): 118-132.

Dodds, W.B. and K.B. Monroe. 1985. The effect of brand and price information on subjective product evaluations, p. 85-90. In E.C. Hirschman and M.B. Holbrook (eds.). Advances in consumer research, Vol. 12. Association for Consumer Research, Provo, UT.
Hall, C.R. and M.W. Dickson. 2011. Economic, environmental, and health/well-being benefits associated with green industry products and services: A review. J. Environ. Hort. 29:96-103.

Haumann, B. 2012. Consumer-driven U.S. organic market surpasses \$31 billion in 2011. Organic Trade Association 2012 Organic Industry Survey.

Hawkins, G., S.E. Burnett, and L.B. Stack. 2012. Survey of consumer interest in organic, sustainable, and local container-grown plants in Maine. HortTechnology 22:817-825.

Hensher, D.A. and J.M. Rose. 2009. Simplifying choice through attribute preservation or nonattendance: Implications for willingness to pay. Transp. Res. Part E Logist. Trans. Rev. 45:583-590.

Jacoby, J., J.C. Olson, and R.A. Haddock. 1971. Price, brand name, and product composition characteristics as determinants of perceived quality. J. Appl. Psychol. 55:570-579.

Kardes, F.R., S.S. Posavac, and M.L. Cronley. 2004. Consumer inference: A review of processes, bases, and judgement contexts. J. Cons. Psych. 14:230-256.

Keeling-Bond, J., D. Thilmany-McFadden, and C. Bond. 2009. What influences consumer choice of fresh produce purchase location? J. Agr. Appl. Econ. 41(1):61-74

Khachatryan, H., B.K. Behe, B. Campbell, C.R. Hall, and J.H. Dennis. 2013. Does eye tracking reveal more about the effects of buying impulsiveness on the green industry consumer choice behavior? Agr. and Appl. Econ. Assoc. Annu. Mtg., Washington, DC.

Lerman, S. 2013. Drying up: Consumers will seek out bargains from mass retailers, hurting nurseries. IBISWorld Industry Report 4442: Nursery \& Garden Stores in the US. 1-32.

Liu, Y.J., Y.J. Mu, Y.G. Zhu, H. Ding, and N.C Arens. 2007. Which ornamental plant species effectively remove benzene from indoor air? Atmos. Environ. 41:650-654.

Long, J.S. and J. Freese. 2006. Regression models for categorical dependent variables using Stata. StataCorp LP, College Station, TX.

Mason, S.C., T.W. Starman, R.D. Lineberger, and B.K. Behe. 2008. Consumer preference for price, color harmony, and care information of container gardens. HortScience 43:380-384.

Mitchell, R.E. 2008. Florida leads nation in foliage plant production. UF/IFAS Extension Service, Charlotte County, FL.

Olson, J.C. and J. Jacoby. 1972. Cue utilization in the quality perception process. Proc. 3rd Ann. Conf. Assoc. Cons. Res. p. 167-179.

Onozaka, Y., G. Nurse, and D. Thilmany McFadden. 2010. Local food consumers: How motivations and perceptions translate to buying behavior. Choices 25(1):1-6.

Organic Trade Association. 2013. Organic food trends. 20 Feb. 2015. <http://www.agmrc. org/markets_industries/food/organic-foodtrends/>.

Phillips, J., E.J. Holcomb, and K.M. Kelley. 2007. Determining interest in value-added planters: Consumer preference and current grower and retailer perceptions. HortTechnology 17:238246.

Reisen, N., U. Hoffrage, and F.W. Mast. 2008. Identifying decision strategies in a consumer choice situation. Judgm. Decis. Mak. 3:641658.

Salois, M.J. and A. Reilly. 2014. Consumer response to perceived value and generic advertising. Agr. Resource Econ. Rev. 43:17-30.

Schiffman, L.G. and L.L. Kanuk. 2007. Consumer behavior, p. 174. 9th ed. Prentice-Hall, Inc. Upper Saddle River, NJ.

Schimmenti, E., A. Galati, V. Borsellino, C. Ievoli, C. Lupi, and S. Tinervia. 2013. Behaviour of consumers of conventional and organic flowers and ornamental plants in Italy. Hort. Sci. 40:162-171

Solano, A.A. 2012. Marketing indoor plants as air cleaners: A choice-based conjoint analysis. Univ. of Florida, Gainesville, PhD Diss. p. 1111

Soreanu, G., M. Dixon, and A. Darlington. 2013. Botanical biofiltration of indoor gaseous pollutants - A mini-review. Chem. Eng. J. 229:585594.

Stewart, A. 2007. Flower confidential: The good, the bad, and the beautiful in the business of flowers. Algonquin Books of Chapel Hill, Chapel Hill, NC.

Sunkhapongvitit, S. and W. Jinsart. 2012. Removal of volatile organic compounds by tropical pot plants. 38th Congress on Science and Technology of Thailand.

U.S. Census Bureau. 2014. State \& county quickfacts. 21 Sept. 2014. <http://quickfacts.census. gov/qfd/states/12000.html $>$.

USDA-NASS. 2012. Census of horticltural specialties. U.S. Dept. Agr. Natl. Agr. Stat. Serv., Washington, DC.

USDA-NASS. 2014. Floriculture crops 2013 summary. U.S. Dept. Agr., Natl. Agr. Stat. Serv., Washington, DC.

Van Loo, E.J., R.M.J. Nayga, H.S. Seo, and W. Verbeke. 2014. Visual attribute non-attendance in a food choice experiment: Results from an eye-tracking study. Agri. and Appl. Econ. Assoc. Annual Mtg., Minneapolis, MN. p. 1-17.

Wehry, R.H., K.M. Kelley, R.D. Berghage, and J.C. Sellmer. 2007. Capturing consumer preferences and interests in developing a state plant promotional program. HortScience 42:574-580.

Winter, N., K. Hood, and D. Tatum. 2001. The Mississippi medallion promotion campaign, SNA Res. Conf. 549-551.

Xu, Z., L. Wang, and H. Hou. 2011. Formaldehyde removal by potted plant-soil systems. J. Hazard. Mater. 192:314-318.

Yiridoe, E.K., S. Bonti-Ankomah, and R.C. Martin. 2005. Comparison of consumer perceptions and preference toward organic versus conventionally produced foods: A review and update of the literature. Renew. Agr. Food Syst. 20:193-205.

Yue, C., J.H. Dennis, B.K. Behe, C.R. Hall, B. Campbell, and R.G. Lopez. 2011a. Investigating consumer preference for organic, local, or sustainable plants. HortScience 46:610-615.

Yue, C., T.M. Hurley, and N. Anderson. 2011b. Do native and invasive labels affect consumer willingness to pay for plants? Evidence from experimental auctions. Agr. Econ. 42:195-205.

Zhang, J., M. Wedel, and R. Pieters. 2009. Sales effects of attention to feature advertisements: A Bayesian mediation analysis. J. Mktg. Res. 46:669-681. 